\title{
Cytotoxicity and Physicochemical Properties of a Promising Root Canal Sealer with Bioinductive Property
}

\section{Fabrício Kitazono de Carvalho ${ }^{1}$, Fernanda Vicioni-Marques ${ }^{1}$, Marília Pacífico Lucisano $^{1 *}$, Bárbara Maria Garbelotti Fortunato ${ }^{1}$, Patrícia Maria Gatón-Hernández ${ }^{2}$, Paulo Nelson-Filho ${ }^{1}$, Raquel Assed Bezerra da Silva ${ }^{1}$ and Léa Assed Bezerra da Silva ${ }^{1}$}

${ }^{1}$ Department of Pediatric Dentistry, University of São Paulo, School of Dentistry of

Ribeirão Preto, Ribeirão Preto, Brazil

${ }^{2}$ Department of Pediatric Dentistry, University of Barcelona, School of Dentistry,

Barcelona, Spain

*Corresponding Author: Marília Pacífico Lucisano, Department of Pediatric Dentistry, University of São Paulo, School of Dentistry of Ribeirão Preto, Ribeirão Preto, Brazil.
Received: July 27, 2021

Published: August 26, 2021

(C) All rights are reserved by Marília Pacífico Lucisano., et al.

\section{Abstract}

The present study evaluated the physicochemical properties and cytotoxicity of AH Plus ${ }^{\circledR}$, BioRoot RCS ${ }^{\circledR}$, Endomethasone $N^{\circledR}$ and Sealapex ${ }^{\circledR}$. The working and setting time, radiopacity, flow and dimensional change were analyzed. Primary cells of human peripheral lymphocytes and MTT assay were used for cell viability evaluation. The results were analyzed by One-way ANOVA and Tukey's posttest $(\alpha=5 \%)$. The longer working time was expressed by Endomethasone. AH Plus showed the longer setting time of 1450 minutes and Sealapex did not take prey. All materials exhibited acceptable radiopacity and flow properties. Regarding dimensional change, Sealapex ${ }^{\circledR}$ did not expressed results and Endomethasone, BioRoot and AH Plus had values in percentage of 1,269, 1,170 and 1,135, respectively. Endomethasone presented the worst cell viability and AH Plus and BioRoot did not express cytotoxicity ( $\mathrm{p}>0.05$ ). BioRoot presents compatible properties to the human body cells and physicochemical properties within the ANSI/ADA parameters.

Keywords: Cytotoxicity; Endodontics; Physicochemical Analysis; Root Canal Filling Materials; Root Canal Obturation

\section{Introduction}

To obtain success in endodontic treatment, selection of the appropriate root canal filling material is essential as the operative technique. Endodontic cements are generally irritating to the periapical tissues [1]. Some authors demonstrated that when performing the condensation of root canal filling material, extravasation may occur toward the periapical tissues, stimulating cellular and inflammatory responses [2]. Moreover, these materials can be extravasated in the form of "puffs", and the components derived from these materials may come into direct contact with the tissues through numerous connections [3], which leads to late irritation and repair, also leading to possible postoperative discomfort [4].

The root canal filling materials are classified according to their chemical composition. Thus, these materials must have satisfactory physicochemical properties such as easy introduction into the root canal, hermetic sealing of the root canal, resistance to contraction, being insoluble in buccal fluids, bacteriostatic or improper for microbial proliferation, radiopaque, not interfering with tooth color, sterile, non-irritating to the periapical tissues and be easy to remove when necessary [5]. 
According to ISO 10993-5 (International Standard Organization) [6], the first test to evaluate the biocompatibility of any material for use in biomedical devices is the in vitro cytotoxicity assay, and the MTT test evaluates the viability [7].

In this study, we were able to evaluate the properties of a new root canal sealant with bio-inductive potential (BioRoot ${ }^{\circledR}$ ) in physicochemical studies as well as cytotoxicity, compared to those al- ready widely used clinically (AH Plus ${ }^{\circledR}$, Endomethasone ${ }^{\circledR}$ and Sealapex ${ }^{\circledR}$ ). In addition, we used human lymphocytes for analysis of MTT, which is still scarcely found in the specific literature.

\section{Materials and Methods}

Four root canal sealers used in permanent teeth were evaluated: AH Plus ${ }^{\circledR}$, Endomethasone $\mathrm{N}^{\circledR}$, BioRoot $\operatorname{RCS}^{\circledR}$ and Sealapex ${ }^{\circledR}$ (Table 1).

\begin{tabular}{|c|c|c|}
\hline Material & Component & Ingredients \\
\hline AH Plus ${ }^{\circledR}$ (Dentsply, Konstanz, Germany) & Paste A & $\begin{array}{l}\text { Epoxy resin, bisphenol-A and bisphenol-B, calcium tungstate, } \\
\text { zirconium oxide, silica, iron oxide }\end{array}$ \\
\hline $\begin{array}{l}\text { BioRoot }{ }^{\circledR} \text { (Septodont, Saint-Maur-des-Fossés, } \\
\text { France) }\end{array}$ & & Tricalcium silicate and zirconium oxide \\
\hline $\begin{array}{l}\text { Endomethasone } \mathrm{N}^{\circledR} \text { (Septodont, Paris, } \\
\text { France) }\end{array}$ & Liquid & Eugenol \\
\hline \multirow[t]{2}{*}{ Sealapex ${ }^{\circledR}$ (Kerr, Orange, USA) } & Base paste & Calcium oxide, zinc oxide, sulfonamides, silica \\
\hline & Catalyst paste & $\begin{array}{l}\text { Bismuth trioxide, polymethylmethacrylate, methylsalicylate, titanium } \\
\text { dioxide, silica, pigments, isobutylsalicylate }\end{array}$ \\
\hline
\end{tabular}

Table 1: Composition of each material analyzed and manufacturer.

The physicochemical tests were performed following ANSI/ ADA Specification no 57 [8]. For all tests, it was performed in triplicate and obtained an arithmetic mean.

For powder-liquid/paste-paste ratio, $3 \mathrm{~g}$ of the powder of the cement to be tested was weighed, placing that material on a glass plate. With a graduated pipette, $0.20 \mathrm{~mL}$ of the appropriate liquid was deposited in the center of the plate. The material was spatulated with $n^{\circ} .24 \mathrm{~F}$ spatula. After consolidation of the desired consistency and annotation of the spatulation time, the remaining powder was weighed in the glass plate, subtracting the amount of powder effectively used for the spatulation. For cements that are presented in paste form, an amount equivalent to $5 \mathrm{~cm}$ of each paste was used, enough to fill each specimen, following the same protocols of the test described previously.

The working time comprises the period from the beginning of the mixing of the material until the material can be manipulated without impairing your properties.
For the setting time, Polyvinylchloride (PVC) rings with $10 \mathrm{~mm}$ diameter and $2 \mathrm{~mm}$ height were used for each cement tested, which remained on a $1 \mathrm{~mm}$ thick glass plate $25 \mathrm{~mm}$ wide and $75 \mathrm{~mm}$ long. The cements were handled according to the manufacturer's instructions and placed inside the rings until they were completely filled. The whole set remained in a humidified incubator at $37^{\circ} \mathrm{C}$. After 30 minutes of initiation of the mixing, a 112g Gillmore type needle and active tip $2 \mathrm{~mm}$ in diameter was placed vertically on the surface of the material. The use of the needle was repeated until it did not cause more marks in the cement tested, which evidenced the initial prey of the material. Subsequently, a Gillmore type needle of $454 \mathrm{~g}$ and active tip of $1.06 \mathrm{~mm}$ in diameter was placed vertically on the surface of the material. The insertion of the needle was repeated until it stopped marking the cement, which indicated the final prey of the material. The setting time was elapsed between the start of the blend and the time at which the Gillmore needle marks were no longer visible on the surface of the tested cement.

To the radiopacity test, acrylic plates $1 \mathrm{~mm}$ thick, $1 \mathrm{~cm}$ wide and $4.5 \mathrm{~cm}$ long were made, with four perforations of $5 \mathrm{~mm}$ internal 
diameter each. Each perforation of the plate was filled with one of the tested materials, on which was placed a sheet of glass wrapped in a sheet of cellophane paper. This whole set was pressed in such a way that the excess cement was removed and thus a sample of $1 \mathrm{~mm}$ thickness per $5 \mathrm{~mm}$ diameter of each material was obtained.

The materials were inserted into the specimen following the sequence according to the setting time of the material, from the longest to the shortest time. In this way, the samples were ready for the radiographic evaluation, simultaneously, at the end of a period equivalent to three times the setting time of the materials. Period of storage in a humidified incubator at $37^{\circ} \mathrm{C}$ and relative humidity of $95 \%$.

Each acrylic plate, already filled with the root canal sealers, was placed in front of the radiographic sensor with a focus-object distance of $30 \mathrm{~cm}$ and on the side of the plate, a $99 \%$ aluminum ladder (alloy 1100) was placed, with a thickness varying from 1 to $10 \mathrm{~mm}$, with uniform steps of $1 \mathrm{~mm}$, which in a same radiographic outlet, allowed the comparison between the steps of the aluminum ladder and the respective samples. Later, radiographic images of the materials and ladder samples were obtained with occlusal radiographic film and X-ray apparatus, at the institutional Clinic of Pediatric Dentistry, with focus-film distance of $30 \mathrm{~cm}$ and adjusted for exposure of $70 \mathrm{kVp}$ and $7 \mathrm{~mA}$, for 0.2 seconds. The films were processed and dried on automatic developer. Radiographs were positioned in a professional negatoscope and scanned with a digital camera, and the images were stored in Jpeg format. For the analysis of radiographic images, the histogram of intensity of the tone scales was used in the "luminosity channel" of the Image J computer program (Version 1.52i 26 November 2018).

In the flow test, the materials were handled in the optimum consistency according to the manufacturers' recommendations, obtaining a volume of $0.5 \mathrm{ml}$ adjusted in $5.0 \mathrm{ml}$ Luer syringe. Each cement was deposited on a glass plate $10 \mathrm{~cm}$ wide and $10 \mathrm{~cm}$ long. After 180 seconds of the start of the manipulation, a set consisting of a glass plate and an additional charge of $120 \mathrm{~g}$ was deposited on the materials. After 10 minutes, additional weight was removed, and the largest and smallest diameters of the disks were measured by a digital caliper.

The dimensional change test was made according to the modification proposed by Carvalho-Júnior., et al. [9] according to the
ANSI/ADA specification $n^{\circ} .57$, where three teflon molds should be made as $3.58 \mathrm{~mm}$ high and $3 \mathrm{~mm}$ diameter. The molds were placed on a glass plate with a thickness of $1 \mathrm{~mm}$ by $25 \mathrm{~mm}$ in width and $75 \mathrm{~mm}$ in length, which should be wrapped with a thin sheet of cellophane paper.

The molds were filled with slight excess of material at the upper end. Afterwards, a glass slide wrapped with cellophane paper was pressed against the top surface of the mold. The assembly was held firmly together with the aid of a letter-shaped clamp C. After $5 \mathrm{mi}$ nutes of commencement of mixing, the assembly shall be brought into a chamber with $95 \%$ relative humidity and $37^{\circ} \mathrm{C}$. After the minimum time interval of three times the set time of each material, the assembly was removed from the interior of the chamber. The ends of the mold containing the sample was sanded under irrigation of distilled and deionized water with a granulation sandpaper 600 in order to regularize its surface. Samples were removed from the molds and the length of each was measured with the aid of a caliper. Afterwards, the samples were placed in glass containers containing $2.24 \mathrm{ml}$ of deionized distilled water, at $37^{\circ} \mathrm{C}$ for 30 days.

After this period, the samples were removed from the container and the excess water was removed with the aid of absorbent paper. A new length measurement of each sample was performed. The values for the dimensional change were obtained by applying the following formula, according to ANSI/ADA specification $n^{\circ}$. 57:

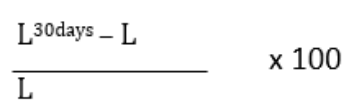

Where $\mathrm{L}^{30 \text { days }}$ is the length of the sample after 30 days under the conditions of the experiment and $L$ is the initial length of the sample.

For the evaluation of the cytotoxicity of root canal obturator cements by MTT assay the present study was approved by the institutional Research Ethics Committee.

This test follows the ISO 10993-12 and each trial was done in triplicate. Blood samples were obtained from six adult voluntary donors, aged 18 - 35 years, of both genders, healthy, non-smokers, who were not exposed to radiation in the last three months and who did not use antibiotics or other medicines for a period of three weeks. Samples of $10 \mathrm{~mL}$ of blood were obtained using a syringe and disposable needles by a health professional with experience 
in phlebotomy at the institutional Clinic of Pediatric Dentistry. Extracts of the materials were prepared immediately after their manipulation, carried out according to the manufacturer's instructions, at a concentration of $0.1 \mathrm{~g} / \mathrm{ml}$ and kept in a humidified incubator at $37^{\circ} \mathrm{C}$ for 24 hours, then filtered and conditioned in a refrigerator at $4^{\circ} \mathrm{C}$ for a maximum period of 30 days.

Lymphocytes were isolated from the volunteers' whole blood by differential centrifugation using Ficoll density gradient, according to the manufacturer's protocol. Lymphocytes were collected in falcon-type plastic tubes, washed and resuspended at $4 \times 10^{5}$ cells/ $\mathrm{mL}$ in RMPI 1640 medium supplemented with $10 \%$ fetal bovine serum and a mixture of antibiotics (penicillin and streptomycin). After 24 hours of incubation at $37^{\circ} \mathrm{C}$ and $5 \%$ of $\mathrm{CO}_{2}$ in a humid atmosphere, the experiments were performed.

For the MTT assay, lymphocytes were isolated $\left(1.0 \times 10^{6}\right)$ in 96-well plates, followed by incubation for 24 hours at $37^{\circ} \mathrm{C}$ in a humidified incubator containing $5 \% \mathrm{CO}_{2}$, the cells being treated thereafter with $100 \mu \mathrm{l}$ of culture medium supplemented with fetal bovine serum (negative control) or $100 \mu \mathrm{L}$ of each extract at different dilutions $(1: 2-50 \mathrm{mg} / \mathrm{mL}, 1: 4-25 \mathrm{mg} / \mathrm{mL}, 1: 8$ - 12,5 mg/ $\mathrm{mL}, 1: 16-6.25 \mathrm{mg} / \mathrm{mL}, 1: 32-3.125 \mathrm{mg} / \mathrm{mL}$ ). The experimental positive control received $100 \mu \mathrm{L}$ of a solution of methylmethanesulfonate (MMS), which is an alkylating and carcinogenic agent, which causes DNA double strand breaks, and the plate is again brought to the incubator for 24 hours at $37^{\circ} \mathrm{C}$. After treatment, wells received $20 \mu \mathrm{l}$ of MTT [3-(4,5-dimethylthiazol-2yl)-2-5-diphenyl-2H-bromo tetrazolate] ( $500 \mu \mathrm{g} / \mathrm{ml}$, final concentration) and the plates were incubated again for 3 hours at $37^{\circ} \mathrm{C}$ and $5 \% \mathrm{CO}_{2}$. The plates were then centrifuged at 1500 rpm for 5 minutes and inverted to discard the supernatant. The formed formazan is insoluble and precipitates in the well, needing to be solubilized before reading; for this, $100 \mu$ of DMSO (dimethylsulfoxide) were added to each well. The plates were kept under stirring until complete dissolution of the crystals (approximately 20 minutes) and then the absorbance at $570 \mathrm{~nm}$ was determined in a Powerwave XS2 microreader. The percentage of cell viability was calculated from the formula: \% viable cells $=($ treatment absorbance $\times 100) /$ mean of the negative control.

The validity of the assay was determined from the responses of the cells to the treatment by the positive controls (MMS) and negative (RPMI-1640 culture medium supplemented with fetal bovine serum). Cellular control was performed by microscopic observation of culture wells that received only the culture medium.

The results were analyzed by GraphPad Prism $5^{\circledR}$ software using the One-way ANOVA method and Tukey's post-test. The level of significance was $5 \%$.

\section{Results}

Figure 1 and table 2 demonstrate the results for the physicochemical tests. Figure 2 demonstrates the results for cytotoxicity test.

The powder-liquid/paste-paste ratio expressed similar values for AH Plus ${ }^{\circledR}$ and BioRoot ${ }^{\circledR}(0,66$ and 0,63 , respectively) and similar values for Endomethasone ${ }^{\circledR}$ and Sealapex ${ }^{\circledR}(0,46$ and 0,45 , respectively).

The longer working time was expressed by Endomethasone ${ }^{\circledR}$ $\left(2,66\right.$ minutes), followed by $\mathrm{AH}$ Plus ${ }^{\circledR}$, Sealapex ${ }^{\circledR}$ and BioRoot ${ }^{\circledR}$ $(1,66 ; 1,33$ and 1 , respectively) ( $p>0,05)$.

\begin{tabular}{|l|c|c|c|c|c|c|}
\hline Material & $\begin{array}{c}\text { Powder-liquid/paste- } \\
\text { paste ratio (grams) }\end{array}$ & $\begin{array}{c}\text { Working time } \\
\text { (minutes) }\end{array}$ & $\begin{array}{c}\text { Setting time } \\
\text { (minutes) }\end{array}$ & $\begin{array}{c}\text { Radiopacity } \\
\text { (millimeters) }\end{array}$ & $\begin{array}{c}\text { Flow (mil- } \\
\text { limeters) }\end{array}$ & $\begin{array}{c}\text { Dimensional change } \\
\text { (percentage) }\end{array}$ \\
\hline AH Plus & $0,66 \pm 0.15^{\mathrm{a}}$ & $1,66 \pm 0.57^{\mathrm{a}}$ & $1450 \pm 18.01^{\mathrm{a}}$ & $150,23 \pm 8.87^{\mathrm{a}}$ & $39.68 \pm 3.57^{\mathrm{a}}$ & $1,135 \pm 0.02^{\mathrm{a}}$ \\
\hline Endomethasone & $0,46 \pm 0.07^{\mathrm{a}}$ & $2,66 \pm 1.15^{\mathrm{a}}$ & $606.7 \pm 12.66^{\mathrm{b}}$ & $121.85 \pm 16.44^{\mathrm{a}}$ & $34.22 \pm 5.80^{\mathrm{a}}$ & $1,269 \pm 0.03^{\mathrm{b}}$ \\
\hline Sealapex & $0,45 \pm 0.10^{\mathrm{a}}$ & $1,33 \pm 0.57^{\mathrm{a}}$ & $0.0 \pm 0.0^{\mathrm{c}}$ & $134.37 \pm 4.03^{\mathrm{a}}$ & $35.73 \pm 5.49^{\mathrm{a}}$ & $0.0 \pm 0.0^{\mathrm{c}}$ \\
\hline BioRoot & $0,63 \pm 0.02^{\mathrm{a}}$ & $1 \pm 0.0^{\mathrm{a}}$ & $255 \pm 15.72^{\mathrm{d}}$ & $138,70 \pm 2,55^{\mathrm{a}}$ & $23.81 \pm 4.62^{\mathrm{b}}$ & $1,170 \pm 0.03^{\mathrm{a}}$ \\
\hline
\end{tabular}

Table 2: Mean values for powder-liquid/paste-paste ratio (grams), working time (minutes), setting time (minutes), radiopacity (millimeters of aluminum), flow test (millimeters) and dimensional change (millimeters) and standard deviation (DP) for different materials. Different letters indicate a statistically significant difference between the materials $(p<0.05)$. 

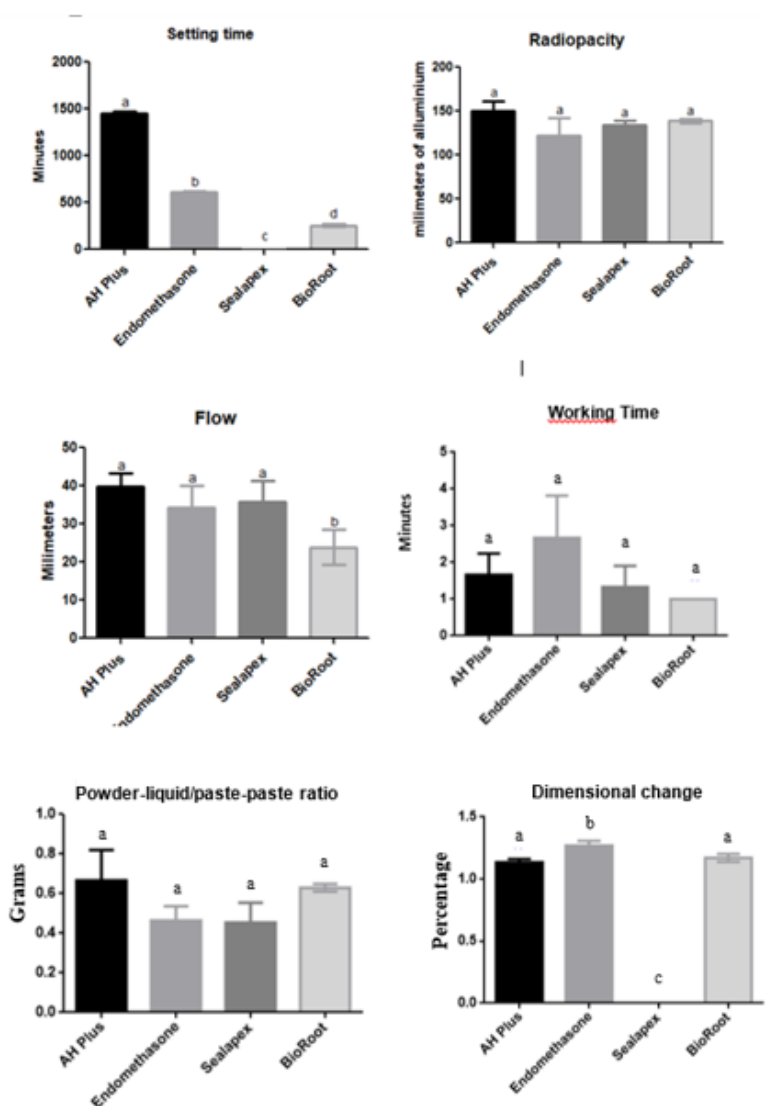

Figure 1: Representative graphs of setting time, radiopacity, flow test, working time, powder-liquid/paste-paste ratio and dimensional change for $A H$ Plus $®$, Endomethasone $N \bowtie$, Sealapex $®$ and BioRoot RCS®. Different letters mean statistically significant difference between the materials $(p<0.05)$.

For the setting time, AH Plus ${ }^{\circledR}$ showed a mean setting time of 1450 minutes, a value compatible with that reported by the manufacturer. Endomethasone $\mathrm{N}^{\circledR}$ does not have the setting time quoted by the manufacturer, but in our analyzes we can observe an average time of 606 minutes. Sealapex ${ }^{\circledR}$ did not take prey even in a period of 168 hours. BioRoot RCS ${ }^{\circledR}$ showed an average setting time of 255 minutes, close to the maximum time set by the manufacture (4 hours).

In the radiopacity test, all materials exhibited radiopacity above $3 \mathrm{~mm}$ aluminum as recommended by ANSI/ADA. AH Plus ${ }^{\circledR}$ presented the highest mean value (150.23 mmAL) and Endomethasone $\mathrm{N}^{\circledR}$ presented the lowest mean (121.85 mmAL) in comparison with the other materials tested.
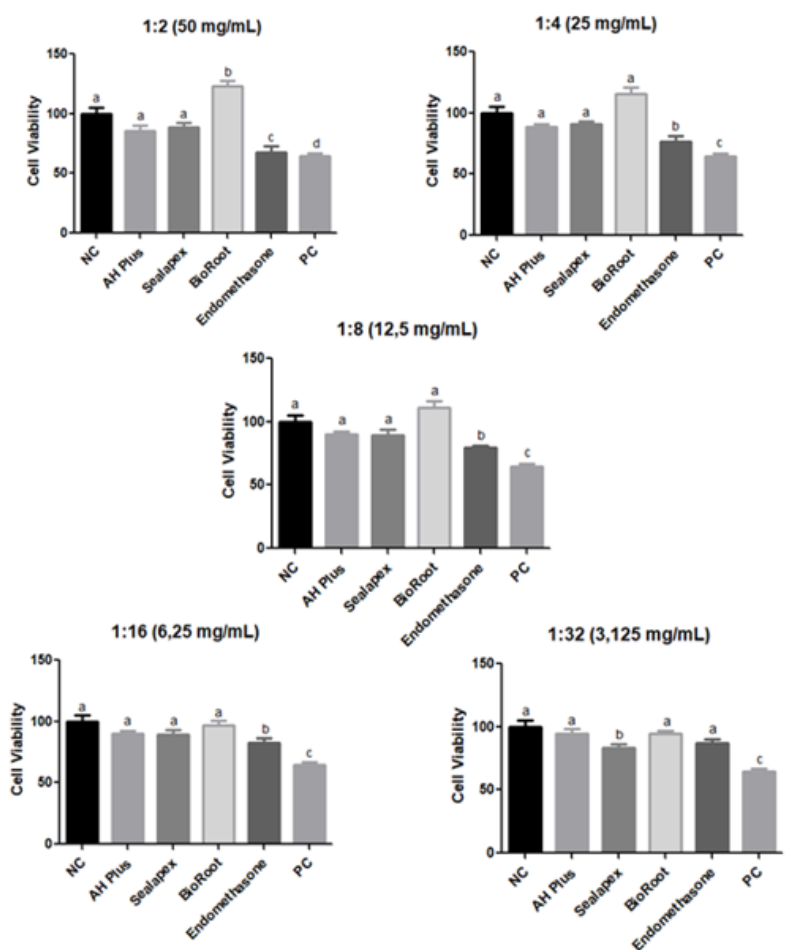

Figure 2: Representative graphs of cytotoxicity assay by MTT cell viability evaluation for AH Plus ${ }^{\circledR}$, Sealapex $\AA$, Endomethasone $\mathrm{N} \AA$ and BioRoot RCS $\AA$ materials, compared to positive (PC) and negative (NC) controls at the dilutions of 1:2, 1:4, 1:8, 1:16, 1:32. Different letters indicate a statistically significant difference for each material $(p<0.05)$.

According to ISO 6876:2012, a root canal sealer must not have a diameter of less than $17 \mathrm{~mm}$ in the flow test. Statistical analysis showed that AH Plus ${ }^{\circledR}$ presented the highest mean value (39.68 $\mathrm{mm})$ and BioRoot ${ }^{\mathbb{B}}$ presented the lowest mean value for this test (23.81 mm).

Sealapex ${ }^{\circledR}$ did not expressed results for dimensional change, because it did not take prey in the time of the study. Endomethasone ${ }^{\circledR}$, BioRoot $^{\circledR}$ and AH Plus ${ }^{\circledR}$ had values in percentage of $1,269,1,170$ and 1,135 , respectively.

In the MTT assay, Endomethasone $\mathrm{N}^{\circledR}$ presented the worst cell viability, not expressing cytotoxicity only at 1:32 dilution. For Sealapex $^{\circledR}$, lymphocyte culture presented significantly lower cell viability at the 1:32 dilution when compared to the negative control. AH Plus ${ }^{\circledR}$ and BioRoot ${ }^{\circledR}$ did not express cytotoxicity at any of 
the concentrations evaluated ( $p>0.05)$, indicating optimal levels of cell viability.

\section{Discussion}

The first test was the powder-liquid/paste-paste ratio test. This is important to determine the necessary quantity of the material to be used when it is spatulated so that its physicochemical characteristics are guaranteed.

An endodontic sealer should have a long working time so that the professional, without much experience, can execute a shutter technique with efficiency. In this study, the longest working time was found to Endomethasone (2,66 minutes), and the shortest working time was for BioRoot (1 minute).

According to ANSI/ADA Specification $\mathrm{n}$-57, a root canal sealer should not have a setting time greater than $10 \%$ of that determined by the manufacturer. Also, all root canal sealer materials must have radiopacity equivalent to or greater than $3 \mathrm{~mm}$ of aluminum. However, root canal filling materials should have radiopacity enough to distinguish between materials and adjacent anatomical structures to facilitate the evaluation of the quality of the obturation, which can only be obtained by radiographic examination [9]. For the dimensional change, recommends the maximum permissible limit of $1 \%$ of contraction, but does not apply to the possibility of expansion. Thus, a sidewalling would be preferable to a contraction, which promotes the adaptation of the obturator material within the root canal $[9,10]$.

For the flow test, ISO $6872: 2012$ set a minimum of $17 \mathrm{~mm}$ as the acceptable diameter of the formed disk by the shutter cement.

AH Plus ${ }^{\circledR}$ presents zirconium oxide, iron oxide and calcium tungstate, which conferred the highest radiopacity and the longer setting time of the cements analyzed in the present study, since these radiopacifying agents present low solubility in water [11]. These results are according to the findings of Carvalho-Júnior., et al. and Resende., et al. $[9,12]$. Sealapex ${ }^{\circledR}$ did not set in the experimental phase of this study ( 1 week), which agrees with previous findings $[13,14]$.

AH Plus ${ }^{\circledR}$ presented the highest mean value for the flow test $(39.68 \mathrm{~mm})$ and BioRoot ${ }^{\circledR}$ presented the lowest mean value (23.81 $\mathrm{mm})$. In the present study, the values were adequate to the ISO minimum for all materials evaluated, as well as related to other findings in the studies of Resende., et al [12]. AH Plus presented an expansion of samples in the dimensional change test, whereas the opposite was observed in BioRoot, which presented a slight contraction, but we could observe the formation of spicules around its surface, characteristics that we can consider according to its bioinductive property, promoting sealing by mineralization and apatite deposition at the root canal wall interface [15]. The results indicate that tricalcium silicate materials such as BioRoot $\mathrm{RCS}^{\circledR}$ promote periapical healing, bone regeneration and sealing by mineralization and apatite deposition at the root canal wall interface [15].

According to Silva., et al. in 2017 [16], a root canal sealer presents lower cytotoxicity as more diluted it is. The indication of a good clinical response is given by the absence of cytotoxic effect. However, the presence of a cytotoxic effect in vitro does not guarantee that the material is toxic when applied in vivo [17].

AH Plus ${ }^{\circledR}$ in the study of Konjhodzic-Prcic., et al. in 2015 [18] demonstrated the lowest cytotoxicity in all evaluated periods, being considered biocompatible. This test evaluated the biocompatibility of root canal sealers from different bases in rat fibroblasts (L929) through a spectrometer. Biocompatibility was determined by the MTT assay, and the levels of uptake by the spectrometer. AH Plus ${ }^{\circledR}$ can be compared in our study, which also presented excellent levels of cell viability, not expressing cytotoxicity in any of the dilutions evaluated.

Teixeira., et al. in 2017 [19] evaluated several groups of endodontic cements in human gingival fibroblasts. Compared to the present study, they also observed that AH Plus ${ }^{\circledR}$ and Sealapex ${ }^{\circledR}$ showed good results regarding cytotoxicity, which is related to previous findings in the literature [20].

The release of formaldehyde by Endomethasone $\mathrm{N}^{\circledR}$ and $\mathrm{AH}$ Plus ${ }^{\circledR}$ was investigated by Leonardo., et al [21]. In the present study, Endomethasone $\mathrm{N}^{\circledR}$ showed cytotoxicity in all dilutions, when compared to the positive control, presenting as the most cytotoxic among the evaluated materials. This finding was probably due to the release of eugenol necessary for the manipulation of Endomethasone $\mathrm{N}^{\circledR}$ [22] and to hydrocortisone and thymol also present in this cement, which are known to be cytotoxic substances. 
Silva, Santos and Zaia, in 2013 [23], studied the cytotoxic effects of eight root canal sealers, among them AH Plus ${ }^{\circledR}$, Endomethaso$\mathrm{ne}^{\circledR}$ and Sealapex ${ }^{\circledR}$. Fibroblasts (3T3 cells) were placed in contact with the samples of newly engineered cements. They observed that Endomethasone ${ }^{\circledR}$ presented low cell viability until the second week; however, after this period, it showed good cellular viability. In our study, we observed that Endomethasone $\mathrm{N}^{\circledR}$ showed cytotoxicity at the dilutions $1: 2 ; 1: 4 ; 1: 8 ; 1: 16$; but at the dilution of $1: 32$ it did not express a statistically significant difference, as observed in previous studies cited, where cell viability was impaired up to a certain period.

Sealapex ${ }^{\circledR}$ demonstrated good tissue repair responses [16]. These results can be attributed by the dissolution of calcium and hydroxyl ions, which increases the $\mathrm{pH}$ of the periapical region, favoring the repair, exerting antimicrobial activity, promoting the degradation and inactivation of lipopolysaccharides of the bacterial plasma membrane [24]. In addition, it induces biological sealing with deposition of calcified tissue in the apical foramen and is associated with favorable repair processes, inducing the formation of mineralized tissue and acting in the control of inflammatory root resorption [21].

According to recent studies, BioRoot $\operatorname{RCS}^{\circledR}$ presented excellent biocompatibility in all concentrations of the extracts both in the fresh material and after setting time. In direct contact with the cells, BioRoot RCS ${ }^{\circledR}$ was not cytotoxic and did not affect cell viability and morphology. Cellular growth was not adversely affected [25]. For our study, BioRoot RCS $^{\circledR}$ was kept in contact via solution eluate. Thus, it was evaluated at different dilutions that did not express significant levels of cytotoxicity. In comparison to the other materials in our study, both BioRoot $\operatorname{RCS}^{\circledR}$ and AH Plus ${ }^{\circledR}$ presented the best levels of cell viability, indicating a great potential of these obturator materials for the choice clinically, if based only on cytotoxicity.

\section{Conclusion}

Considering the specific conditions of this work, based on the methodology used and the results obtained, it can be concluded that $\mathrm{AH}$ Plus ${ }^{\circledR}$, Endomethasone $\mathrm{N}^{\circledR}$, Sealapex ${ }^{\circledR}$ and BioRoot $\mathrm{RCS}^{\circledR}$ have met the parameters established by ANSI/ADA for physicochemical tests. Endomethasone $\mathrm{N}^{\circledR}$ demonstrated cytotoxicity characteristics on lymphocytes at different concentrations, being the most cytotoxic among the studied materials; AH Plus ${ }^{\circledR}$, Sealapex ${ }^{\circledR}$ and BioRoot RCS $^{\circledR}$ showed acceptable levels of cell viability.

\section{Acknowledgements}

Undergraduate scholarship by Fundação de Amparo à Pesquisa do Estado de São Paulo (grant no.2016/24410-1).

\section{Bibliography}

1. Garrido AD., et al. “Cytotoxicity evaluation of copaíba oil-based root canal sealer compared to three commonly used sealers in endodontics". Journal of Dental Research 12.2 (2015): 121126.

2. Cotti E., et al. "Cytotoxicity evaluation of a new resin-based hybrid root canal sealer: an in vitro study". The Journal of Endodontics 40.1 (2014): 124-128.

3. Koch MJ., et al. "Formaldehyde release from ground root canal sealer in vitro". The Journal of Endodontics 27.6 (2001): 396397.

4. Rodríguez-Lozano FJ., et al. "Cytoprotective effects of melatonin on zoledronic acid-treated human mesenchymal stem cells in vitro". Journal of Craniofacial Surgery 43.6 (2015): 855-862.

5. Ozorio JEV. "Evaluation of the amount of formaldehyde released by some endodontic cements". (PhD Thesis). Ribeirão Preto, BR: University of São Paulo (2012).

6. ISO 10993-5 - Biological evaluation of medical devices - Part 5: Tests for in vitro cytotoxicity (Third edition). Switzerland (2009).

7. Cintra LTA., et al. "Evaluation of the Cytotoxicity and Biocompatibility of New Resin Epoxy-based Endodontic Sealer Containing Calcium Hydroxide". The Journal of Endodontics 43.12 (2017): 2088-2092.

8. International Standard Organization (ISO) 6876. Dentistry Root canal sealing materials (2012).

9. Carvalho-Junior JR., et al. "Solubility and dimensional change after setting of root canal sealers: a proposal for smaller dimensions of test samples". The Journal of Endodontics 33.9 (2007): 1110-1116.

10. Marín-Bauza GA., et al. "Physicochemical properties of endodontic sealers of different bases". Journal of Applied Oral Science 20.4 (2012): 455-461.

11. Sousa-Neto MD., et al. "Effect of different grades of gum rosins and hydrogenated resins on the solubility, disintegration, and dimensional alterations of Grossman cement". The Journal of Endodontics 25.7 (1999): 477-480. 
12. Resende LM., et al. "A comparative study of physicochemical properties of AH Plus, Epiphany, and Epiphany SE root canal sealers". International Endodontic Journal 42.9 (2009): 785793.

13. Allan NA., et al. "Setting times for endodontic sealers under clinical usage and in vitro condition". The Journal of Endodontics 27 (2001): 421-423.

14. Ingle J., et al. "Obturation of the radicular space". Endodontics. Hamilton: BC Decker Inc (2002): 571-668.

15. Siboni F., et al. "Properties of BioRoot RCS, a tricalcium silicate endodontic sealer modified with povidone and polycarboxylate". International Endodontic Journal 2 (2017): e120-e136.

16. Silva LAB., et al. "Novel endodontic sealers induce cell cytotoxicity and apoptosis in a dose-dependent behavior and favorable response in mice subcutaneous tissue". Clinical Oral Investigations 21.9 (2017): 2851-2861.

17. Martins VJ., et al. "Cytotoxicity of root canal sealers on endothelial cell culture”. Brazilian Dental Journal 24.1 (2013): 1520.

18. Konjhodzic-Prcic A., et al. "Evaluation of Biocompatibility of Root Canal Sealers on L929 Fibroblasts with Multiscan EX Spectrophotometer". Acta Informatica Medica 23.3 (2015): 135-137.

19. Teixeira L., et al. "Cytotoxicity Evaluation of Root Canal Sealers Using an In Vitro Experimental Model with Roots”. Brazilian Dental Journal 28.2 (2017): 165-171.

20. Gomes-Filho JE., et al. "Rat tissue reaction to MTA FILLAPEX®". Dental Traumatology 28.6 (2012): 452-456.

21. Leonardo MR., et al. "Release of formaldehyde by 4 endodontic sealers". Oral Surgery, Oral Medicine, Oral Pathology, Oral Radiology, and Endodontology 88.2 (1999): 221-225.

22. Schwarze T., et al. "The cellular compatibility of five endodontic sealers during the setting period". The Journal of Endodontics 28 (2002): 784-786.

23. Silva EJ., et al. "Long-term cytotoxic effects of contemporary root canal sealers". Journal of Applied Oral Science 21.1 (2013): 43-47.

24. Willershausen I., et al. "In vitro analysis of the cytotoxicity and the antimicrobial effect of four endodontic sealers". Head and Face Medicine 10 (2011): 7-15.
25. Collado-González M., et al. "Biocompatibility of three new calcium silicate-based endodontic sealers on human periodontal ligament stem cells". International Endodontic Journal 50 (2017): 875-884.

\section{Volume 5 Issue 9 September 2021 (C) All rights are reserved by Marília Pacífico Lucisano., et al.}

